\title{
Analisis Kemampuan Pemahaman Konsep Dasar Mahasiswa dalam Mengidentifikasi Karakteristik dan Menyelesaikan Soal Pemodelan Matematika
}

\author{
Elika Kurniadi $^{1}$, Darmawijoyo ${ }^{2}$, Weni Dwi Pratiwi ${ }^{3}$ \\ 1,2,3 Universitas Sriwijaya, J1 Palembang-Prabumulih KM 32 Indralaya, Indonesia \\ Pengiriman: 10/Desember/2019; Diterima: 24/Maret/2020; Publikasi: 31/Maret/2020 \\ DOI: https://doi.org/10.31629/jg.v5i1.299
}

\begin{abstract}
Abstrak
Penelitian ini adalah penelitian desain pembelajaran yang menghasilkan lintasan belajar dalam mata kuliah pemodelan matematika di salah satu program studi pendidikan matematika FKIP di Sumatera Selatan. Lintasan belajar yang telah didesain bertujuan menghasilkan mahasiswa yang memiliki kompetensi dalam mengkonstruksi soal pemodelan matematika untuk pembelajaran matematika di kelas. Desain pembelajaran ini diujicobakan selama 1 semester pada mata kuliah pemodelan matematika. Sebelum mencapai kompetensi mengonstruksi soal pemodelan matematika, pemahaman konsep dasar mahasiswa tentang pemodelan matematika merupakan tujuan awal yang akan dicapai dari desain pembelajaran ini. Oleh sebab itu, artikel ini akan memberikan gambaran secara menyeluruh terhadap pemahaman konsep dasar mahasiswa dalam mata kuliah pemodelan matematika pada aktivitas pertama dan kedua yang merupakan bagian dari lintasan belajar mata kuliah pemodelan matematika. Subjek penelitian ini adalah 31 mahasiswa yang mengikuti mata kuliah pemodelan matematika tahun akademik 2018/2019. Penelitian ini dimulai dari tahap perencanaan yaitu analisis kajian materi pemodelan matematika dan perancangan Hypothetical Learning Trajectory (HLT). Selanjutnya, tahap eksperimen yaitu pengambilan data observasi, wawancara dan catatan lapangan selama dilaksanakan perkuliahan. Tahap terakhir penelitian yaitu retrospective analysis dari data yang telah dikumpulkan. Hasil dari penelitian ini adalah diperoleh deskripsi kemampuan pemahaman konsep dasar pemodelan matematika dalam mengidentifikasi karakteristik dan menyelesaikan pemodelan matematika.
\end{abstract}

Kata kunci: pemodelan matematika; HLT; lintasan belajar; penelitian desain pembelajaran.

\begin{abstract}
This research is an educational design research that generate learning trajectories in mathematics modeling courses in the program study of mathematics education in FKIP of South Sumatera. The learning trajectory that has been designed aims to get the competencies in constructing mathematical modeling tasks in classroom learning. This learning design was experimented for 1 semester in mathematics modeling courses. Prior to achieving the competence in constructing mathematical modelling tasks, understanding students' basic concepts of mathematical modelling is the initial goal to be achieved from this learning design. Therefore, this article will provide a comprehensive explanation of understanding the basic concepts of students in mathematics modelling courses in the first and second activity, which is part of the trajectory of learning courses in mathematical modeling. The subjects of this study were 31 students in the 2018/2019 academic year who enrolled the mathematics modeling course. This research starts from the planning stage, namely the analysis of the study of mathematical modeling

*Penulis Korespondensi

Email Address: elikakurniadi@gmail.com

Handphone : : +62 852-7310-2562
\end{abstract}




\section{JURNAL GANTANG. Maret 2020; V(1): 9 - 18 \\ p-ISSN. 2503-0671 \\ e-ISSN. 2548-5547}

material and the design of the Hypothetical Learning Trajectory (HLT). Next, the experimental stage is observation, interviews and field notes during the lecture. The last stage of the research is a retrospective analysis of the data that has been collected. The results of this study are obtained a description about understanding the basic concept of identyfing characteristic and solving the mathematical modeling problem.

Keywords: mathematical modelling; HLT; learning trajectory; design research

\section{Pendahuluan}

Pemodelan matematika adalah suatu proses penggunaan matematika untuk menggambarkan, menganalisis, membuat prediksi atau menerjemahkan fenomena dunia nyata (Blum \& Ferri, 2009). Dalam proses pemodelan matematika menggunakan bahasa matematika untuk mengukur dan menganalisis dunia nyata, menggunakan matematika untuk mengekplorasi dan mengembangkan pemahaman tentang masalah dunia nyata, serta melakukan suatu interaksi proses pemecahan masalah dimana matematika dipakai untuk menyelidiki dan memperdalam suatu pemahaman (Garfunkel \& Monthomery, 2019).

Pendekatan pembelajaran pemodelan matematika ialah pendekatan yang memfokuskan pembelajaran matematika dengan menggunakan konteks fenomena dunia nyata sehingga penggunaan matematika dapat dipakai dalam menggambarkan suatu proses pemahaman, menyederhanakan, dan memecahkan masalah ke dalam bentuk pemodelan matematika agar interaksi pemahaman lebih dalam (Bahmaei, 2011). Pemodelan matematika sudah dianggap sebagai salah satu tujuan dari proses pentingnya pendidikan matematika dalam hal memperkenalkan dan menjaga pendidikan matematika yang relevan untuk perubahan pendidikan mengarah lebih baik (Eric et al, 2015). Penerapan pembelajaran matematika tidak dapat dipisahkan dari penggunaan model dan proses pemodelan, terutama pada masalah matematika yang mengharuskan siswa terlibat aktif dalam kelompok diskusi tentang fenomena dunia nyata sehingga siswa dituntut untuk pandai dalam menggunakan proses pemodelan agar mereka dapat mengakses dunia nyata ke bentuk matematika (Ang, 2006). Hal ini dikarenakan siswa sangat sering berurusan dengan masalah dalam konteks nyata yang hanya dapat diakses dan dimanipulasi jika menggunakan model matematika. Proses pemodelan yang dilakukan siswa inilah merupakan suatu jembatan bagi mereka mengkontruksikan permasalahan matematika dengan kehidupan dunia nyata (Ang, 2006).

Akan tetapi, penerapan pembelajaran pemodelan matematika masih jarang dilakukan oleh guru karena guru mengalami kesulitankesulitan untuk mengaplikasikan pembelajaran berbasis pemodelan matematika di kelas (Blum \& Ferri, 2009; Burkhardt, 2006; Freudenthal, 2012). Menurut regulasi Permendiknas nomor 16 tahun 2007, salah satu kompetensi yang harus dimiliki oleh seorang guru ataupun calon guru adalah kompetensi professional (Republik Indonesia, 2007). Kompetensi professional adalah kemampuan yang dimiliki oleh seorang guru dalam memahami materi/konten matematika lalu mengaplikasikan teori belajar mengajar dalam prakteknya di kelas. Oleh sebab itu, mahasiswa program studi pendidikan matematika sebagai seorang calon guru matematika di sekolah perlu memiliki kompetensi yang mendalam terkait pembelajaran pemodelan matematika (Kurniadi et al., 2019). Kompetensi tersebut dapat diperoleh mahasiswa dalam mata kuliah pemodelan matematika. Calon guru yang memiliki kompetensi pemodelan matematika yang diharapkan akan dapat mengatasi kesulitan-kesulitan dalam mengaplikasikan penerapan pembelajaran pemodelan matematika di kelas.

Berdasarkan pentingnya mata kuliah pemodelan matematika bagi mahasiswa prodi pendidikan matematika perlu dibuat suatu desain pembelajaran dalam mata kuliah pemodelan matematika. Penelitian ini bertujuan untuk menghasilkan desain pembelajaran yang 
merujuk kepada metode penelitian design research dengan mengonstruksi Hypothetical Learning Trajectory (HLT) yang nantinya akan menjadi Local Instruction Theory (Teori Pembelajaran Lokal) dalam mata kuliah pemodelan matematika. Teori pembelajaran lokal adalah teori yang dihasilkan sesuai dengan data di lapangan setelah dilaksanakannya HLT di kelas (Gravemeijer, 2004). Dalam artikel ini dibahas teori lokal pembelajaran untuk tahapan yang pertama yaitu memahami konsep dasar pemodelan matematika sehingga akan dianalisis kemampuan pemahaman konsep dasar mahasiswa dalam mengidentifikasi karakteristik dan menyelesaikan soal pemodelan matematika.

\section{Metode Penelitian}

Subjek penelitian ini adalah 31 mahasiswa yang mendaftar dalam mata kuliah pemodelan matematika di salah satu Program Studi Pendidikan Matematika Fakultas Keguruan dan Ilmu Pendidikan di Sumatera Selatan. Metode penelitian yang digunakan dalam penelitian ini adalah penelitian desain pembelajaran (educational design research). Menurut Gravemeijer (2004), educational design research yang juga bisa disebut penelitian pengembangan pendidikan merupakan penelitian yang terbentuk dari pembelajaran eksperimen di kelas yang mengembangkan desain rangkaian pembelajaran dan menghasilkan teori lokal pembelajaran. Oleh sebab itu, penelitian desain pembelajaran ini bertujuan untuk merumuskan dan mengembangkan Hypothetical Learning Trajectory (HLT) yang akan menjadi Local Instruction Theory (Teori Lokal Pembelajaran). Dalam satu siklus penelitian desain pembelajaran memiliki tiga tahapan yaitu preliminary design, experiment dan retrospective analysis (Gravemeijer, 2004).

\subsection{Preliminary design}

Pada tahap awal ini, peneliti mengkonstruk Hypothetical Learning Trajectory (HLT) yang berfungsi sebagai petunjuk dalam mendesain panduan pembelajaran. HLT memuat tujuan dan aktivitas dari pembelajaran dalam mata kuliah pemodelan matematika. Gambar 1 berikut ini adalah HLT yang telah dikembangkan dalam tahap awal pendesainan pembelajaran

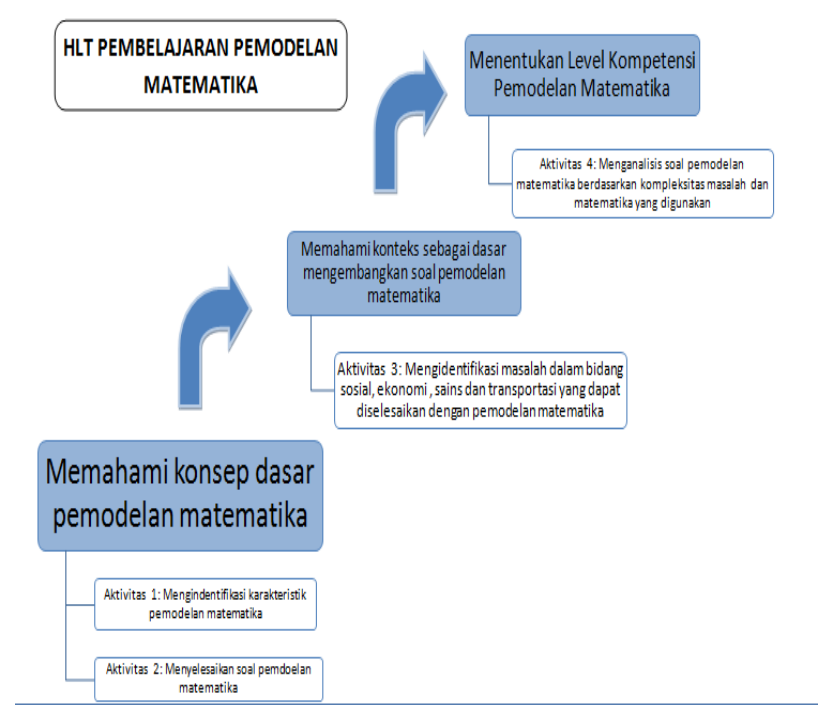

Gambar 1. HLT mata kuliah pemodelan matematika

Tahapan pengembangan soal berbasis pemodelan matematika menggunakan model pengembangan Tessmer yaitu

Tahap formative evaluation yang meliputi:

a. Self Evaluation yaitu analisis materi dan desain soal

b. Prototyping yaitu expert review, one-toone, small group dan field test

\subsection{Experiment}

Di tahap experiment, HLT yang telah dirancang akan diujicobakan kepada mahasiswa. Uji coba ini akan melihat apakah hal-hal yang ada dalam preliminary design sesuai dengan kenyataan atau tidak. Hal-hal yang terjadi selama fase experiment akan menjadi perbaikan atau modifikasi dari rancangan HLT. Fungsi HLT dalam tahap ini adalah untuk memfokuskan kegiatan pembelajaran, proses pembelajaran dan observasi. 
JURNAL GANTANG. Maret 2020; V(1): 9 - 18

p-ISSN. 2503-0671

e-ISSN. 2548-5547

\subsection{Retrospective Analysis}

Pada tahap ini, semua data yang diperoleh dari tahap experiment akan dianalisis. Proses analisisnya yaitu antar komponen dalam HLT sebelum pembelajaran dan setelah pembelajaran, dilanjutkan dengan analisis kemungkinan penyebabnya sesuai dengan teori yang ada sebelumnya, dan sintesis dari perbaikan/modifikasi dari rancangan HLT yang akan digunakan untuk siklus selanjutnya.

\section{Hasil dan Pembahasan}

Pada artikel ini, kami akan membahas tentang teori pembelajaran lokal untuk aktivitas pertama dan kedua dari HLT/desain pembelajaran yang telah dibuat untuk mata kuliah pemodelan matematika. Sesuai dengan HLT, tujuan utama dari aktivitas pertama dan kedua adalah mahasiswa mendapatkan pemahaman tentang konsep dasar pemodelan matematika. Sebanyak 31 mahasiswa yang mendaftar dalam mata kuliah pemodelan matematika dan akan dianalisis bagaimana pemahaman konsep dasar pemodelan matematika. Data yang diambil adalah hasil dari observasi selama perkuliahan berlangsung dan hasil kerja mahasiswa setelah menyelsaikan soal pemodelan matematika. Berikut ini akan dijelaskan tentang dua aktivitas awal yang terdapat dalam HLT.

3.1 Aktivitas 1: Mengidentifikasi karakteristik dari soal pemodelan matematika

Aktivitas pembelajaran diawali dengan memberikan 3 permasalahan pemodelan matematika kepada mahasiswa yaitu permasalahan tentang biaya tarif angkutan online, permasalahan tentang berat badan ideal, dan permasalahan tentang resep makanan. Ketiga permasalahan menyajikan data sebenarnya sesuai dengan permasalahan di dunia nyata. Berikut ini adalah gambar 2 yang menunjukkan ketiga permasalahan pemodelan matematika.
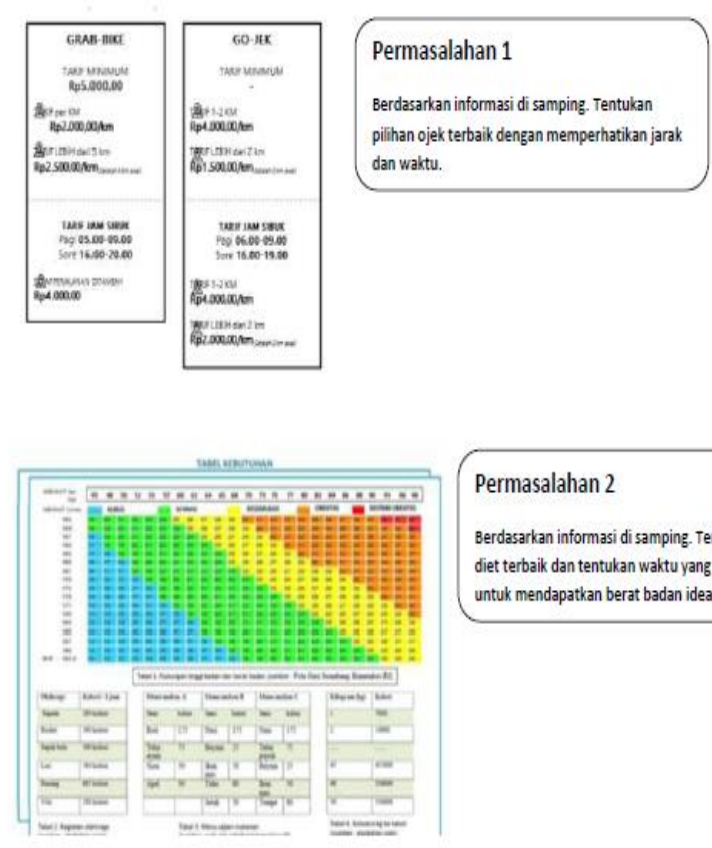

Permasalahan 2

Berdasarkan informasi di samping. Tentukan menu diet terbaik dan tentukan waktu yang dibutuhkan untuk mendapatkan berat badan ideal.

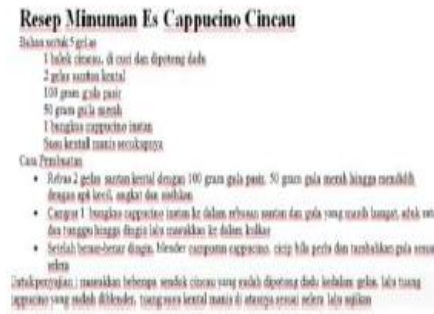

Permasalahan 3

Berdasarkan informasi di samping. Tentukan banyak bahan dibutuhkan untuk membuat beberapa gelas minuman
Gambar 2. Permasalahan pemodelan matematika

Mahasiswa diminta untuk mengenali apa saja karakteristik yang terdapat dalam permasalahan tersebut. Adapun karakteristik dalam permasalahan pemodelan matematika yaitu: 1) Permasalahan dunia nyata (situasional dan faktual), 2) Masalah terbuka, 3) Permasalahan yang layak diselesaikan, dan 4) Matematika digunakan sebagai alat untuk mencari solusi. Berdasarkan hasil wawancara antara peneliti dan mahasiswa yang dilakukan setelah observasi berlangsung, terdapat beberapa kekeliruan yang dialami mahasiswa dalam memahami makna permasalahan dunia nyata dan masalah terbuka (Kurniadi et al., 2019). Berikut ini transkrip 1 yang merupakan petikan wawancara antara peneliti dan mahasiswa:

Peneliti : Apa yang kamu pahami tentang permasalahan dunia nyata?

Subjek : Permasalahan dalam kehidupan 
sehari-hari

Transkrip 1.

Pada transkrip 1 di atas, peneliti menanyakan tentang makna permasalahan dunia nyata, subjek mengatakan bahwa permasalahan dalam kehidupan sehari-hari adalah permasalahan dunia nyata. Hal ini mengindikasikan adanya pemahaman yang harfiah tentang dunia nyata sebagai kehidupan sehari-hari. Untuk mengukur pemahaman yang lebih dalam mengenai makna kehidupan sehari-hari, peneliti meminta subjek memberikan contoh permasalahan pemodelan matematika seperti pada transkrip di bawah ini.

$\begin{array}{llr}\text { Peneliti } & \text { : Menurutmu, apakah } & \text { setiap } \\ & \text { permasalahan dalam kehidupan } \\ & \text { sehari-hari dapat menjadi } \\ & \text { permasalahan dalam pemodelan } \\ & \text { matematika? } \\ \text { Subjek } & : \text { Ya } \\ \text { Peneliti } & : \text { Mengapa? } \\ \text { Subjek } & : \text { Hmmm, karena dalam permasalahan } \\ & \text { dalam kehidupan sehari-hari } \\ & \text { memerlukan matematika untuk } \\ \text { Peneliti } & \text { mendapatkan solusinya. } \\ \text { Subjek } & \text { Bisakah kamu memberikan contoh? } \\ & : \text { Hmmm, misalnya,permasalahan } \\ \text { Peneliti } & \text { dalam jual beli di pasar? } \\ & : \text { Mengapa hal tersebut masuk ke } \\ & \text { dalam permasalahan pemodelan } \\ \text { Subjek } & \text { matematika karena problem tersebut adalah } \\ & \text { masalah nyata dalam kehidupan } \\ & \text { sehari-hari. }\end{array}$

Transkrip 2.

Berdasarkan transkrip 2 di atas, kita dapat melihat dengan jelas bahwa pemahaman mahasiswa masih rendah tentang makna dari permasalahan kehidupan sehari-hari dalam permasalahan pemodelan matematika. Terlihat bahwa subjek memberikan jawaban dengan raguragu. Selain itu, subjek memberikan contoh tentang permasalah jual beli di pasar dan ketika ditanya apakah hal tersebut termasuk dalam permasalahan dalam pemodelan matematika, subjek hanya memberikan alasan bahwa masalah tersebut terdapat dalam kehidupan sehari-hari.

Menurut Guidlines For Assessment \&
Instruction In Mathematical Modelling Education (2019), terdapat transformasi dalam soal matematika sebagai berikut:

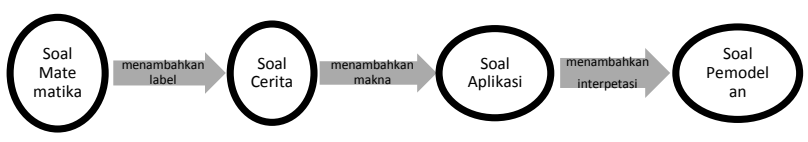

Gambar 3. Transformasi soal matematika

Pada tahapan awal, soal matematika ditambahkan sebuah label/objek benda sehingga soal tersebut menjadi soal cerita, soal cerita yang diberikan makna akan menjadi soal aplikasi, selanjutnya soal aplikasi yang terdapat interpretasi, maka akan menjadi soal pemodelan matematika. Hal ini mensyaratkan adanya sebuah interpretasi dalam permasalahan kehidupan sehari-hari, sehingga permasalahan tersebut dapat dikatakan sebagai sebuah permasalahan pemodelan matematika (Kurniadi et al., 2019).

Untuk dapat megkonstruksi soal pemodelan matematika yang baik, maka permasalahan tersebut harus memiliki indikasi penerapan dalam kehidupan sehari-hari dan memilki interpretasi. Oleh sebab itu, akan dihasilkan sebuah hubungan dalam pemodelan dan dunia nyata sebagai langkah awal dalam proses pemodelan matematika. Hubungan ini akan melalui proses analisis, asimilasi, interpretasi dan validasi penyelesaian (Kurniadi et al., 2019). Jadi, tidak semua permasalahan dalam kehidupan sehari-hari dapat menjadi permasalahan pemodelan matematika.

3.1 Aktivitas 2: Menyelesaikan permasalahan pemodelan matematika

Dalam menyelesaikan masalah matematika, seseorang harus memahami masalah terlebih dahulu dengan menyederhanakan 
JURNAL GANTANG. Maret 2020; V(1): 9 - 18

p-ISSN. 2503-0671

e-ISSN. 2548-5547

masalah, membuat masalah menjadi lebih terstruktur untuk diselesaikan dan membuat suatu model nyata dari situasi awal permasalahan tersebut. Perubahan model nyata ke dalam bentuk model matematika akan menghasilkan suatu persamaan matematika yang akan diselesaikan dengan suatu operasi matematika tertentu (Ebby, 2000). Oleh sebab itu, diperlukan kompetensi matematika untuk dapat menyelesaikan permasalahan dalam pemodelan matematika misalnya kemampuan dalam membaca matematika, bernalar, berkomunikasi, dan menerapkan strategi penyelesaian (Blum \& Niss, 1991). Adapan tujuh tahapan dalam pemodelan matematika yaitu mengonstruksi, membuat struktur, matematisasi, bekerja dengan matematika, interpretasi, validasi dan memaparkan hasil penyelesaian (Blum \& Ferri, 2009)

Aktivitas kedua ini memiliki tujuan agar mahasiswa dapat mengerjakan soal pemodelan matematika sehingga mahasiswa dapat mengenali lebih jelas dan mendalam terkait tahapan-tahapan dari pemodelan matematika. Diharapakan dengan mengerjakan soal maka mahasiswa memiliki pengalaman yang bermakna untuk dapat mengkonstruksi soal pemodelan matematika dengan benar. Secara terperinci, aktivitas kedua ini, mahasiswa diberi petunjuk untuk menyelesaikan permasalahan pemodelan matematika dengan menggunakan empat tahapan penyelesaian yaitu mengidentifikasi masalah, membuat asumsi dan mendefiniskan variabel, menyelesaikan masalah dan terakhir melaporkan solusi dari permasalahan pemodelan matematika. Permasalahan ini dikerjakan secara berkelompok yang terdiri dari 3 hingga 4 orang. Berikut gambar 3 adalah permasalahan tentang memilih ojek online antara grab atau gojek dengan mempertimbangkan syarat jarak dan waktu untuk dapat mendapatkan harga terbaik dari masingmasing ojek online.
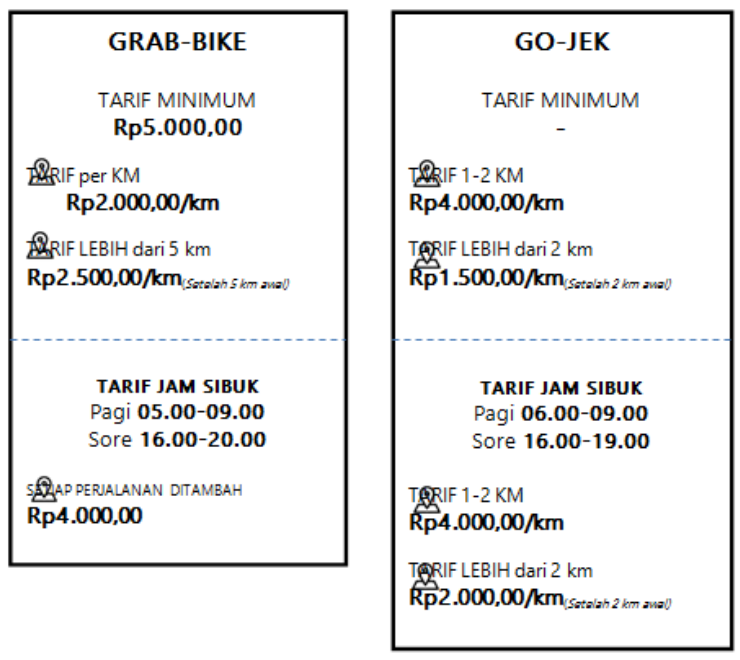

Gambar 3. Permasalahan pemodelan matematika

Berikut ini hasil kerja mahasiswa dalam menyelesaikan permasalahan pemodelan matematika sesuai dengan petunjuk pengejaan menggunakan empat tahapan penyelesaian permasalahan pemodelan matematika:

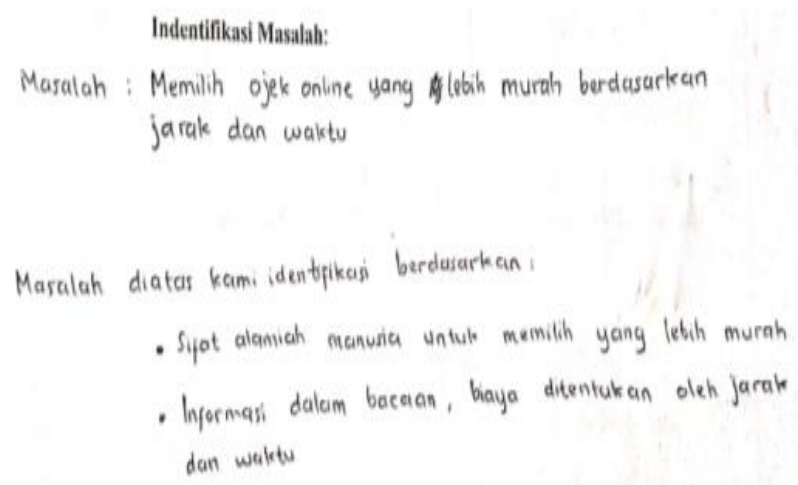

\section{Gambar 4. Hasil kerja 1}

Pada gambar 4 hasil kerja 1 di atas, terlihat bahwa mahasiswa menuliskan kembali masalahnya yaitu memilih ojek online yang lebih murah berdasarkan jarak dan waktu. Proses identifikasi masalah dengan mempertimbahkan sifat alamiah dan informasi dari bacaan. Hal ini menunjukkan bahwa mahasiswa telah dapat mengidentifikasi permasalahan pemodelan matematika dengan baik dan lancar. Pemahaman akan masalah yang baik akan mendukung proses pemodelan matematika selanjutnya yaitu pembentukan asumsi dan mendefinisikan 
variabel.

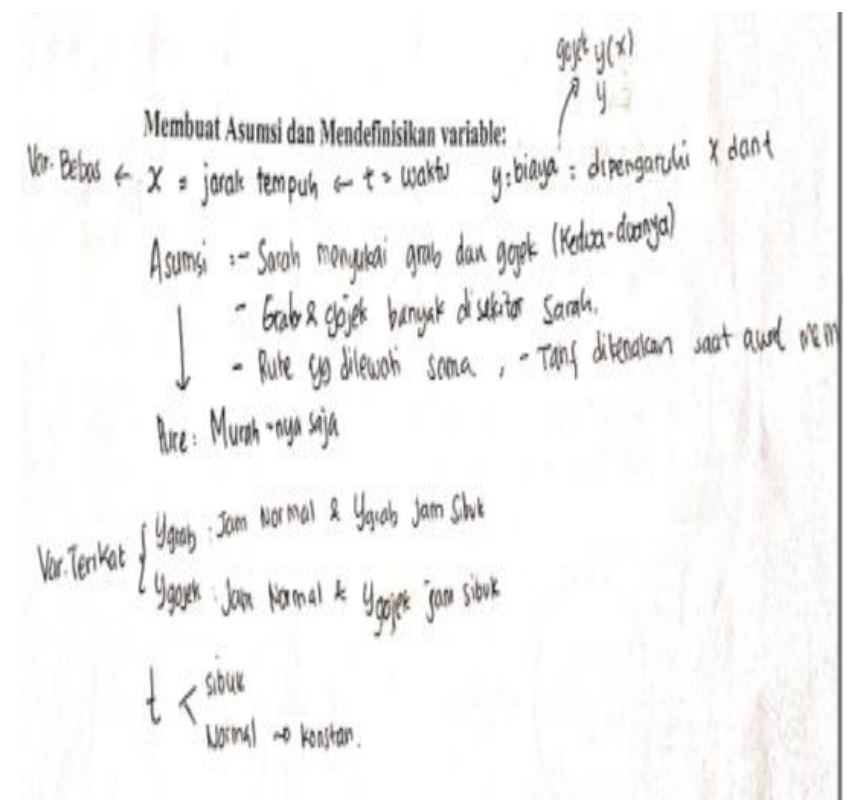

Gambar 5. Hasil kerja 2

Berdasarkan gambar 5 hasil kerja mahasiswa di atas terlihat bahwa mahasiswa menuliskan terlebih dahulu variabel bebas dari masalah ojek online tersebut yaitu variabel $x$ sebagai jarak tempuh, variabel t sebagai waktu dan variabel $y$ sebagai biaya yang dipengaruhi oleh variabel $x$ dan $t$. Variabel bebas tersebut dihasilkan dari asumsi yang diambil dari masalah ini yaitu dengan mengasumsikan bahwa keberadaan ojek online ada di sekitar, tidak ada ketertarikan personal antara kedua ojek online, rute yang akan dilalui sama serta memiliki tarif awal yang normal (atau tidak ada promo antara salah satu ojek online tersebut).

Setelah mendefinisikan variabel bebas yang ada dalam permasalahan pemodelan, terdapat variabel terikat atau variabel yang nilainya dipengaruhi oleh variabel bebas. Dalam permasalahan pemodelan ojek online ini, variabel terikatnya yaitu biaya. Dalam hasil kerja 2, mahasiswa juga mempertimbangkan informasi tentang waktu jam normal dan jam sibuk, pada jam tersebut mempengaruhi tarif biaya per $\mathrm{km}$ untuk ojek online.

Proses pendefinisian variabel sangat penting dilakukan dengan baik dan tepat karena akan mempengaruhi dalam membuat model matematika berupa persamaan matematika (Niss, 2003). Berikut ini gambar 6 adalah hasil kerja siswa dalam membuat formula untuk menyelesaikan masalah sebagai tahapan ketiga dari proses penyelesaian permasalahan pemodelan matematika.

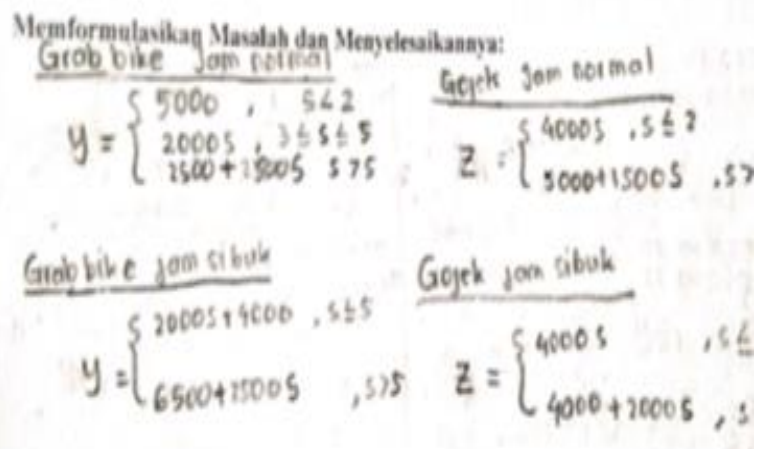

Gambar 6. Hasil kerja 3

Fungsi tangga dihasilkan oleh mahasiswa dari permasalahan pemodelan matematika tentang ojek online ini. Fungsi tangga ini mendefinisikan dua atau tiga fungsi tergantung dari interval masing-masing fungsi. Pada masing-masing fungsi untuk grab dan gojek terdapat dua fungsi tangga yang dibentuk berdasarkan dari jam normal dan jam sibuk. Pada jam normal dan sibuk terdapat perbedaan tarif per km yang dikenakan untuk mendapatkan biaya perjalanan. Sesuai dengan pendefinisian variabel pada tahap sebelumnya, maka variabel $y$ atau $z$ yang merupakan fungsi dari biaya bergantung pada variabel $s$ (jarak tempuh) dan $t$ (waktu normal dan waktu sibuk).

Fungsi untuk Grab bike

Di jam normal, terdapat tarif minimum yaitu Rp 5.000 untuk jarak perjalanan kurang dari $2 \mathrm{~km}$, sehingga $f_{1}(s)=5000 ; s<2$, sedangkan sesuai informasi bahwa untuk jarak tempuh lebih dari $5 \mathrm{~km}$, maka tarif per $\mathrm{km}$ nya adalah Rp 2.500 dan Rp 2.000 untuk kurang dari $5 \mathrm{~km}$, sehingga $f_{2}(s)=2000 s ; 2 \leq s<5$ dan $f_{3}(s)=2500 s-2500 ; s>5$. Untuk fungsi yang ketiga ini, memang diperlukan suatu penalaran yang tepat untuk menghasilkan persamaan yang sesuai dengan situasi. Jika kita 
JURNAL GANTANG. Maret 2020; V(1): 9 - 18

p-ISSN. 2503-0671

e-ISSN. 2548-5547

perhatikan hasil kerja 3, terdapat kekeliruan dalam membuat persamaan ketiga ini.

Selanjutnya, fungsi biaya untuk jam sibuk berbeda dengan fungsi biaya pada jam normal sesuai dengan informasi yang diberikan pada permasalahan. Di jam sibuk, tidak terdapat tarif minimum sehingga hanya akan dibuat dua fungsi sesuai dengan interval dari jarak tempuh.

$$
y=f(s)= \begin{cases}2000 s+4000 & \text { untuk } 0<s \leq 5 \\ 2500 s+1500 & \text { untuk } s>5\end{cases}
$$

Di dalam pemodelan matematika, satu tahapan akan mempengaruhi tahapan lainnya. Sebelumnya, pada hasil kerja 3 terdapat kekeliruan untuk $f_{3}(s)$ akibatnya pada fungsi dengan jarak tempuh lebih dari $5 \mathrm{~km}$ juga menghasilkan fungsi yang keliru di jam sibuk dengan jarak tempuh lebih dari $5 \mathrm{~km}$. Oleh sebab itu, di dalam proses pemodelan matematika terdapat suatu pengulangan proses.

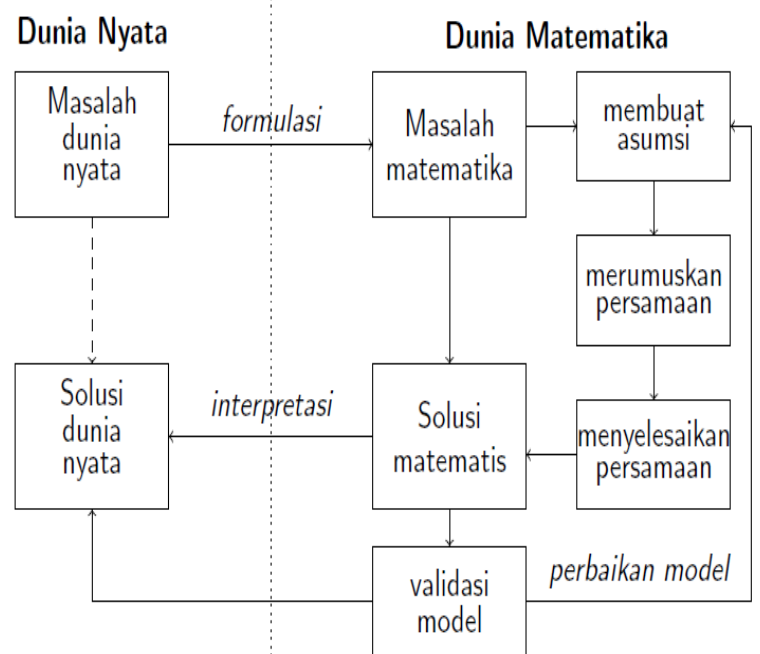

Gambar 7. Proses pemodelan matematika

Pada proses pemodelan tersebut tampak nyata bahwa terdapat suatu siklus dalam membuat asumsi, merumuskan masalah, menyelesaikan masalah, solusi matematis, validasi model, perbaikan model dan membuat asumsi kembali. Hal ini menandakan bahwa pemodelan matematika akan memberikan pengalaman matematika yang lebih dalam bagi siswa baik itu dalam menalar, menghitung, berargumentasi dan lain sebagainya (Kurniadi et al., 2019).

\section{Fungsi untuk Gojek}

Di jam normal tidak terdapat tarif minimum sehingga hanya dua fungsi yang dihasilkan yaitu $f_{1}(s)=4000 s ; s<2$, dan $f_{2}(s)=1500 s+5000 ; s>2$. Hasil ini sesaui dengan hasil kerja 3 . Selanjutnya, fungsi biaya untuk jam sibuk berbeda dengan fungsi biaya pada jam normal sesuai dengan informasi yang diberikan pada permasalahan. Di jam sibuk pun dibuat dua fungsi sesuai dengan interval dari jarak tempuh.

$y=f(s)=\left\{\begin{array}{cl}4000 s & \text { untuk } 0<s \leq 2 \\ 2000 s+4000 & \text { untuk } s>2\end{array}\right.$

Dari fungsi tangga dari grab bike dan gojek yang telah dibuat, selanjutnya mahasiswa diminta untuk melaporkan hasilnya berupa kesimpulan atau solusi dari permasalahan tentang pilihan ojek online mana yang seharusnya dipilih. Oleh sebab itu, mahasiswa membuat detail situasi dari persamaan yang dibentuk ke dalam bentuk tabel seperti gambar 8 berikut ini

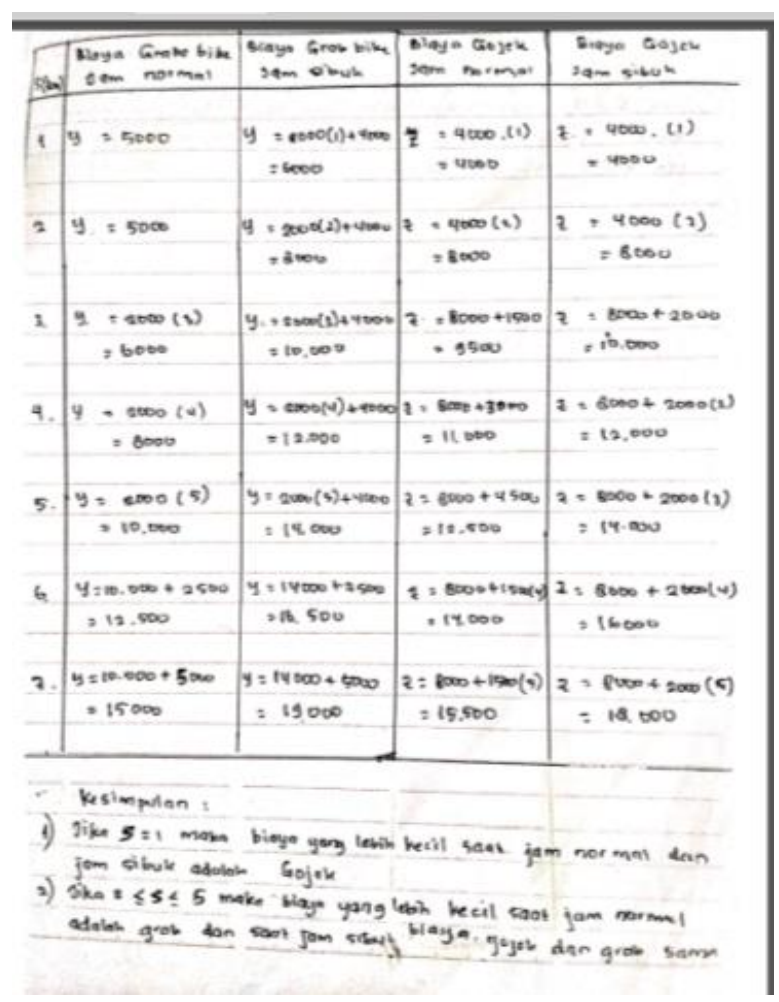

Gambar 8. Hasil kerja 4 
Langkah terakhir dari tahapan pemodelan matematika adalah memberikan interpretasi dari solusi matematika dengan dunia nyata. Pada permasalahan pemodelan matematika tentang ojek online ini, tabel pada hasil kerja 4 di atas memberikan penjelasan yang detail dari biaya, jarak dan waktu baik jam normal ataupun jam sibuk dari masing-masing ojek online (Grab bike dan Gojek). Di akhir penyelesaian terdapat kesimpulan yang diberikan yaitu pilihan ojek online yang menguntungkan sesuai dengan jarak tempuh dan waktu.

Secara keseluruhan, hasil kerja mahasiswa untuk aktivitas kedua ini sudah baik. Setiap kelompok telah melaksanakan setiap tahapan dari pemodelan matematika dengan cukup baik walaupun masih ada beberapa sedikit kekeliruan dalam membentuk persamaan dari permasalahan pemodelan matematika.

Berdasarkan data kemampuan pemahaman konsep dasar mahasiswa dalam menyelesaikan permasalahan dapat terlihat bahwa mahasiswa telah mengikuti proses pemodelan yaitu memformulasikan permasalahan, memilih objek dan hubungan yang tepat dalam permasalahan, merepresentasikan objek dan hubungan dalam bentuk matematika, menggunakan metode matematika untuk medapatkan penyelesaian, menginterpretasikan hasil dan melakukan validitas terhadap proses pemodelan yang dilakukan (Blum \& Ferri, 2009).

\section{Kesimpulan}

Tahapan pertama dari Hypothetical Learning Trajectory yang telah didesain memiliki tujuan untuk mendapatkan pemahaman mahasiswa tentang konsep dasar pemodelan matematika. Tahapan pertama ini memiliki dua aktivitas dan dari kedua aktivitas ini telah dihasilkan suatu lokal instruksi pembelajaran sesuai dengan data untuk mata kuliah pemodelan matematika. Secara terperinci, pada aktivitas pertama diberikan 3 soal pemodelan matematika, dan mahasiswa memiliki kemampuan yang cukup baik untuk melakukan identifikasi karakteristik dari permasalahan pemodelan matematika yaitu 1) Permasalahan dunia nyata (situasional dan faktual), 2) Masalah terbuka, 3)Permasalahan yang layak diselesaikan, dan 4)matematika digunakan sebagai alat untuk mencari solusi. Selanjutnya, pada aktivitas kedua, kemampuan mahasiswa mengerjakan soal pemodelan matematika sudah baik menggunakan empat tahapan penyelesaian yaitu mengidentifikasi masalah, membuat asumsi dan mendefiniskan variable, menyelesaikan masalah dan terakhir melaporkan solusi dari permasalahan pemodelan matematika.

\section{Ucapan Terima kasih}

Penelitian ini didanai oleh Anggaran DIPA BLU Universitas Sriwijaya tahun 2019 dengan SK Rektor Penelitian Sateks Nomor 0016/UN9/SK.LP2M.PT/2019

\section{Referensi}

Ang, K. C. (2006). Mathematical modelling, technology and H3 mathematics.

Bahmaei, F., \& others. (2014). Mathematical modelling in primary school, advantages and challenges. Journal of Mathematical Modelling and Application, 1(9), 3-13.

Blum, W., \& Ferri, R. B. (2009). Mathematical modelling: Can it be taught and learnt? Journal of Mathematical Modelling and Application, 1(1), 45-58.

Blum, W., \& Niss, M. (1991). Applied mathematical problem solving, modelling, applications, and links to other subjects - State, trends and issues in mathematics instruction. Educational Studies in Mathematics, 22(1), 37-68.

Burkhardt, H. (2006). Modelling in mathematics classrooms: Reflections on past developments and the future. $Z D M$, 38(2), 178-195.

Chan, C., Ng, K., Widjaja, W., \& Seto, C. (2015). A case study on developing a teacher's capacity in mathematical modelling. The Mathematics Educator, 16(1), 1-31.

Ebby, C. B. (2000). Learning to teach mathematics differently: The interaction between coursework and fieldwork for preservice teachers. Journal of 
JURNAL GANTANG. Maret 2020; V(1): 9 - 18

p-ISSN. 2503-0671

e-ISSN. 2548-5547

Mathematics Teacher Education, 3(1), 69-97.

Freudenthal, H. (2012). Mathematics as an educational task. Springer Science \& Business Media.

Garfunkel, S \& Monthomery, M. (2019). GAIMME : Guidlines For Assesment \& Instruction In Mathematical Modelling Education, Second edition. Philadelphia: COMAP\& SIAM.

Gravemeijer, K. (2004). Local instruction theories as means of support for teachers in reform mathematics education. Mathematical Thinking and Learning, 6(2), 105-128.

Kurniadi, E., Darmawijoyo, D., Scristia, S., \& Astuti, P. (2019). Kompetensi mahasiswa dalam mata kuliah pemodelan matematika berbasis pengembangan soal. Jurnal Elemen, $5(1), 54-63$.

Ng,K.E.D. (2013). Teacher readiness in mathematical modelling: Are there difference between pre-service and inservice teachers? In G. Stillman et al. (Eds.), Teaching mathematical modelling: to research and practice, 2013: 339-352.

Niss, M. (2003). Mathematical competencies and learning of mathematics: The Danish KOM Project. In; Gagatsis, A./Papastavridis, S. (Eds), $3^{\text {rd }}$ Mediterranean Conference on Mathematical Education. Athens: The Hellenic Mathematical Society, 115-124

Republik Indonesia. (2007). Permendiknas Nomor 16 Tahun 2007 tentang Standar Kualifikasi Akademik dan Kompetensi Guru. Jakarta : Sekretariat Negara.

Widjaya, W. (2013) Building awareness of mathematical modeling in teacher education: a case study in indonesia. In Stillman, A.G., et al. Teaching Mathematical modeling: Connecting Research and Practice. 2013:583-595. 